\title{
MORPHOLOGICAL VARIATIONS IN ASTACUS ASTACUS L. AND AUSTROPOTAMOBIUS PALLIPES (LEREBOULLET) POPULATIONS
}

\author{
D. SINT (1), J. DALLA VIA (2), L. FÜREDER (1)
}

(1) Institute of Zoology and Limnology, University of Innsbruck, Technikerstraße 25, 6020 Innsbruck, Austria.

E-Mail: daniela.sint@uibk.ac.at

(2) Research Centre for Agriculture and Forestry Laimburg, 39040 Ora/Auer, Italy.

Reçu le 20 décembre 2004

Received December 20, 2004

Accepté le 14 avril 2005

Accepted April 14, 2005

\begin{abstract}
Genetic studies on crayfish have shown that the differences between crayfish populations can be greater than it is assumed at the first view. Studies have demonstrated that some of these differences are not only found in the genome but are also expressed in the morphology of crayfish. Statistical analysis of a large set of morphological parameters from several autochthonous crayfish populations of Astacus astacus (Linnaeus, 1758) and Austropotamobius pallipes (Lereboullet, 1858) were applied in order to define distinct characteristics of different populations. Preliminary results of a multivariate discriminant analysis suggest that some morphological parameters are useful attributes to identify distinct populations. A positive correlation was obtained between carapace shape, described as the ratio postorbital length/width of carapace, and carapace curvature. Our results showed that the development and application of methods to characterize the uniqueness of individual populations is important, especially when they may have adapted in various ways to specific environmental conditions due to separation for a long time.
\end{abstract}

Key-words: Crayfish, endangered species, morphometry, environmental adaptation.

\section{VARIATIONS MORPHOLOGIQUES DES POPULATIONS D'ASTACUS ASTACUS L. ET D'AUSTROPOTAMOBIUS PALLIPES (LEREBOULLET)}

\section{RÉSUMÉ}

Des études génétiques sur des écrevisses ont démontré que les différences entre les populations d'écrevisses peuvent être plus importantes qu'on ne pouvait le supposer a priori. Des études ont démontré que certaines différences ne sont pas uniquement génétiques mais aussi morphologiques. Des analyses statistiques sur un grand nombre de paramètres morphologiques sur plusieurs populations d'Astacus astacus (Linnaeus, 1758 ) et d'Austropotamobius pallipes (Lereboullet, 1858) ont été menées pour définir des caractères distinctifs des différentes populations. Les résultats préliminaires d'une analyse multivariée discriminante suggèrent que quelques caractéristiques morphologiques sont utiles pour identifier des populations distinctes. Si la forme de la carapace, ici décrite par le coefficient de la longueur post orbitale/largeur de la carapace, et la courbure de la carapace sont utilisés, une corrélation positive entre ces deux paramètres est obtenue. 
Nos résultats montrent que le développement et l'utilisation de méthodes pour caractériser l'unicité de populations individuelles est importante, spécialement en considérant les différences liées à des adaptations aux conditions environnementales, apparues lors d'une longue séparation temporelle.

Mots-clés: écrevisse, espèce menacée, morphométrie, adaptation environnementale.

\section{INTRODUCTION}

All native European crayfish species are endangered due to different causes like crayfish plague, land use and river engineering (GHERARDI and $\mathrm{HOLDICH}, 1999$; FÜREDER and HANEL 2000; SKURDAL and TAUGBOL, 2001; FÜREDER and REYNOLDS 2003). Therefore, species protection measures are strongly needed to prevent a further decline of populations. As has been shown in several cases (HUOLILA, MARJOMÄKI and LAUKKANEN, 1997; SINT and FÜREDER, 2004) the outcome of (re)introduction programmes is best when the used stocking material used fits best into its new habitat. It is known that organisms tend to adapt in various ways to their specific environmental conditions and some of these adaptations may also influence the morphology. Although, there may exist some cases where, all the variability can be explained either by phenotypical variation of the genome (IMRE, MCLAUGHLIN and NOAKS, 2002) or by genotypical differences (PAKKASMAA, 2001), in most cases both mechanisms play an important role (JERRY and CAIRNS, 1998; BEGG, FRIEDLAND and PEARCE, 1999; IMRE, MCLAUGHLIN and NOAKS, 2002). According to SWAIN and FOOTE (1999) and BEGG, FRIEDLAND and PEARCE (1999), phenotypical variation among populations is not necessarily associated with differences in the genome. However, it can indicate a prolonged separation and consequently the beginning of a differentiation. Thus, phenotypical differences are better suited to analyse short-term effects as well as ongoing differentiations than genetic methods.

Since decades, morphometric measurements combined with multivariate analysis offer a good tool to explore differences between single groups of organisms (SAILA and FLOWERS 1969; CHAMBERS, PAYNE and KENNEDY 1979; WINANS, 1984; MURTA, 2000; PALMA and ANDRADE, 2002). According to these authors, the morphology of an animal usually reflects its environment. For example CHAMBERS, PAYNE and KENNEDY (1979) found correlations between morphological and environmental variation in Cambarellus puer Hobbs (1941). It is further assumed that the morphology depends on genetic information (SAILA and FLOWERS 1969). Therefore, morphometry can well be used for the distinction of single stocks or populations without being as expensive as genetic analysis. One minor problem with morphometry may arise from variations in the absolute size of individuals, but these differences can be excluded by eliminating this character through normalization (CHAMBERS, PAYNE and KENNEDY, 1979) or other size corrections (PALMA and ANDRADE, 2002).

The region of Tyrol consists of North (NT, Austria), South (ST, Italy) and East Tyrol (ET, Austria). While South Tyrol is mainly inhabited by Austropotamobius pallipes (7 populations; FÜREDER et al., 2003) North Tyrol is dominated by Astacus astacus (34 populations) and Austropotamobius torrentium (2 populations; FÜREDER and HANEL, 2000). There are also a few water bodies in Tyrol that are populated by introduced species. Whereas Astacus leptodactylus, Eschscholtz (1823), which occurs in North and East Tyrol, is a European species, Pacifastacus leniusculus (Dana, 1852), (one population each in NT and ST) and Orconectes limosus (Rafinesque, 1817) (one population in ST) are derived from North America and are therefore carrier of the crayfish plague. Fortunately, until now these populations have been restricted to isolated water bodies and have not shown any tendency of dispersion (FÜREDER and HANEL, 2000; FÜREDER, OBERKOFLER and MACHINO, 2002; FÜREDER et al., 2003). 
The aims of this study were to determine whether there are morphological differences between distinct crayfish populations of the noble crayfish and the white-clawed crayfish in Tyrol and if so, which characters are best suited for discriminating among them.

\section{MATERIAL AND METHODS}

Morphological analysis of a total number of 416 crayfish was carried out (120 A. pallipes (AUP) and 296 A. astacus (ASA)). These individuals originated from 4 AUP populations of South Tyrol and 10 ASA populations of North, South and East Tyrol (Table I). According to their regional vicinity, the A. astacus populations were combined into 5 groups, i.e., Mieming (MIE), Reintaler Seen (RTS), Kufstein (KUF), East Tyrol (OST) and South Tyrol (SÜD), whereas A. pallipes were not grouped but investigated as distinct populations (Figure 1, Table I).



Figure 1

Investigated crayfish populations in Tyrol. For grouped Astacus astacus populations the geographic regions are MIE (Mieming), RTS (Reintalerseen), KUF (Kufstein), SÜD (South Tyrol) and OST (East Tyrol). For Austropotamobius pallipes the populations HYP (Hypolithbach), ANG (Angelbach), ENT (Ritscherbach) and KRB (Krebusbach) were studied. (Map: Claude M.E. Hansen).

Figure 1

Populations d'écrevisses étudiées au Tyrol. Les populations d'Astacus astacus ont été regroupées par régions géographiques : MIE (Mieming), RTS (Reintalerseen), KUF (Kufstein), SÜD (Tyrol du Sud) et OST (Tyrol de l'Est). Les populations d'Austropotamobius pallipes ont été étudiées dans les régions suivantes: HYP (Hypolithbach), ANG (Angelbach), ENT (Ritscherbach) et KRB (Krebusbach). (Carte : Claude M.E. Hansen). 


\section{Table I}

Overview of investigated crayfish populations in Tyrol. Numbers in brackets indicate number of crayfish over $60 \mathrm{~mm}$ total length for $A$. pallipes and over $80 \mathrm{~mm}$ total length for $A$. astacus.

Tableau I

Vue d'ensemble des populations d'écrevisses étudiées au Tyrol. Les valeurs entre parenthèses indiquent le nombre d'écrevisses d'une longueur totale supérieure à $60 \mathrm{~mm}$ pour $A$. pallipes et à $80 \mathrm{~mm}$ pour $A$. astacus.

\begin{tabular}{lllcc}
\hline \multirow{2}{*}{ Species } & Population in & Geographic region & \multicolumn{2}{c}{ Measured individuals } \\
& materbody & & $14(14)$ & $16(16)$ \\
& & $21(15)$ & $9(3)$ \\
A. pallipes & Angelbach (ANG) & & $14(9)$ & $16(13)$ \\
& Krebusbach (KRB) & & $21(19)$ & $9(7)$ \\
& Ritscherbach (ENT) & & $19(15)$ & $11(9)$ \\
& Hypolithbach (HYP) & & $13(7)$ & $17(5)$ \\
A. astacus & Krebsbach Mieming & Mieming (MIE) & $23(15)$ & $13(9)$ \\
& Krummsee/Buchsee & Reintalerseen (RTS) & $19(18)$ & $11(6)$ \\
& Frauensee & Reintalerseen (RTS) & $15(15)$ \\
& Berglsteinersee & Reintalerseen (RTS) & $15(15)$ & $15(11)$ \\
& Thiersee & Kufstein (KUF) & $18(16)$ & $12(10)$ \\
& Pfrillsee & Kufstein (KUF) & $20(12)$ & $10(3)$ \\
& Morsbach & Kufstein (KUF) & $14(12)$ & $16(14)$ \\
& Hechtsee & Kufstein (KUF) & $19(19)$ & $11(10)$ \\
& Wiesenbach Gais & South Tyrol (SÜD) & $8(7)$ & $12(11)$ \\
\hline Nikolsdorfer Weiher & East Tyrol (OST) & &
\end{tabular}

All crayfish were caught during night hours either by hand and kept in traps with closed inlets until the next day or caught with baited traps. Then, before releasing the animals back into the water, a total number of 21 morphologic characteristics were recorded for each crayfish. Claw length (CLL), claw width (CLW) and claw height (CLH), length of the claw palm (CPL), length of the claw finger (CFL), rostrum length $(R O L)$ and rostrum width (ROW), head length (HEL) and head width (HEW), areolar length (ARL) and areolar width (ARW), abdomen length (ABL), abdomen width (ABW, at the second abdominal segment) and abdomen height ( $\mathrm{ABH}$, at the second abdominal segment), telson length (TEL) and telson width (TEW), carapace width (CPW), width at the cervical groove (CGW), width of the carapace at the hind edges (CEW), and carapace height (CPH, between the second and third pereiopode) were measured with a vernier caliper to the nearest $0.1 \mathrm{~mm}$ (Figure 2A and B). Total length (TL) was measured to the nearest $1.0 \mathrm{~mm}$ by placing the crayfish in a stretched position on its back on scale paper. All bilateral parameters were measured on the right side except when injuries or regenerations were observed which chiefly affected the claws. In this case, measurements were taken at the left side.

Crayfish males and females are known to show sexual dimorphism (GRANDJEAN et al., 1997; GRANDJEAN and SOUTY-GROSSET, 2000; STREISSL and HÖDL, 2002), thus, the sexes were analyzed separately. Individuals of a TL less than $60 \mathrm{~mm}$ and $80 \mathrm{~mm}$ for Austropotamobius and Astacus, respectively, were excluded from all analysis in order to avoid comparisons between adults and juveniles. As the size at maturity cannot be determined at a certain point due to variations between populations and individuals, the size limit was set with regard to the observations made by CUKERZIS (1988), WESTIN and GYDEMO (1995), HAGER (1996), GRANDJEAN et al. (1997) and STREISSL and HÖDL 

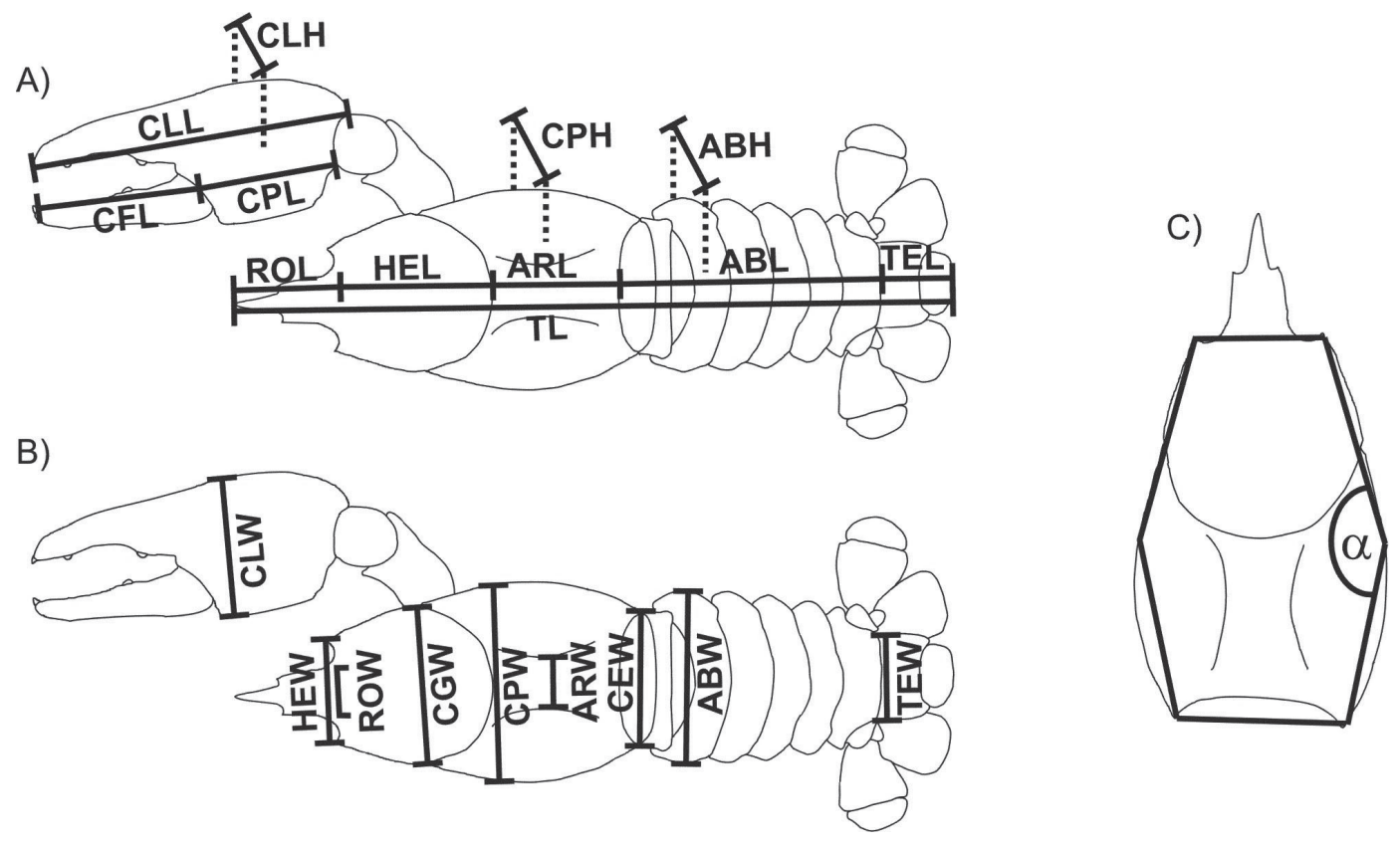

Figure 2

Position of performed measurements (measured lengths and heights $(A)$ and widths (B)) and scheme of definition of the lateral curvature (angle $\alpha$ ) of the carapace (C). ABH - abdomen height, $A B L$ - abdomen length, ABW - abdomen width, ARL - areolar length, ARW - areolar width, CEW - width at the hind edges of the carapace, CFL - claw finger length, CGW - width at the cervical groove, CLH - claw height, CLL - Claw length, CLW - claw width, CPH - carapace height, CPL - claw palm length, CPW - carapace width, HEL - head length, HEW - head width, ROL - rostrum length, ROW - rostrum width, TEL - telson length, TEW - telson width, TL - total length.

\section{Figure 2}

Position des dimensions prises (longueur et hauteur (A) et largeur mesurées (B)) et schéma de la définition des angles latéraux (angle $\alpha$ ) de la carapace (C). ABH - hauteur abdominale, ABL - longueur abdominale, ABW - largeur abdominale, ARL - longueur aréolaire, ARW - largeur aréolaire, CEW - largeur au fond de la carapace, CFL - longueur du doigt de la pince, CGW - largeur au joint cervical, CLH - hauteur de la pince, CLL - longueur de la pince, CLW - largeur de la pince, CPH - hauteur de la carapace, CPL - longueur de la paume de pince, CPW - largeur de la carapace, HEL - longueur de la tête, HEW - largeur de la tête, ROL - longueur du rostrum, ROW - largeur du rostrum, TEL - longueur du telson, TEW - largeur du telson, TL - Longueur totale.

(2002). In addition, groups or populations with less than 10 adult individuals remaining were excluded from multivariate discriminant analysis (HYP and KRB for females and ENT for males of $A$. pallipes, MIE for females and OST for males of $A$. astacus). All data were normalized for size by dividing them with the corresponding postorbital length $(P O L=H E L+A R L)$, and only normalized values are given in this paper. One-way ANOVA (Post-Hoc-Test: Bonferroni) was applied to select those morphometric parameters for each group (species and sex) which differed significantly from other populations. From morphometric parameters with a high correlation $\left(r^{2}>0.7\right)$ only the parameter with the highest significant difference was chosen in order to avoid over-estimations of distinction 
power due to co-correlations. The remaining parameters were used in a multivariate discriminant analysis.

Multivariate discriminant analysis was applied to detect those morphometric parameters out of the whole set which best characterize the different groups. We used the stepwise method, which only gives those variables that contribute most to the discriminant analysis. Cross validation of the classification was applied to evaluate the results of the performed analysis, where each case in the analysis was classified by the functions deduced from all cases except that one (JAMES and MCCULLOCH 1990; HAIR et al., 1998; BÜHL and ZÖFEL, 2002).

As is known from the literature, morphologic characteristics of the carapace can represent an important tool for distinction (CHAMBERS, PAYNE and KENNEDY, 1979; LUTZ and WOLTERS, 1995; SAILA and FLOWERS, 1969). Thus, two additional measures describing the shape of the carapace were included in the analysis: first, the ratio of postorbital length (POL) to carapace width (CPW), and second, the lateral curvature of the carapace calculated as the angle at CPW between HEW and CEW (Figure $2 \mathrm{C}$ ) using the following formula and tested with one-way ANOVA.

$$
\alpha=\arctan \left(\frac{\mathrm{HEL}}{\frac{\mathrm{CPW}-\mathrm{HEW}}{2}}\right)+\arctan \left(\frac{\mathrm{ARL}}{\frac{\mathrm{CPW}-\mathrm{CEW}}{2}}\right)
$$

$\alpha \quad$ lateral curvature of the carapace

ARL areolar length

CEW width of carapace at hind edges

CPW width of carapace

HEL head length

HEW head width at the orbital edges

All the analysis were performed using Microsoft ${ }^{\circledR}$ Excel 2002, SP-2 and SPSS for Windows 11.0.1. Means \pm Standard deviations are given.

\section{RESULTS}

\section{Differences between species and sexes}

The carapace shape was found to be distinctly different between species and sexes. The mean angle of the carapace curvature was $151.3 \pm 3.03$ ( $\min .142 .8$, max. 158.2) degrees for $A$. astacus and $153.7 \pm 3.17$ ( $\min .146 .9$, max. 161.8) for $A$. pallipes, respectively. Significant differences were found between sexes of ASA $(p<0.001)$ but not within AUP ( $p=0.224)$. In addition carapace curvature of males of ASA was significantly different from both sexes of AUP $(p<0.001)$, whereas females of ASA differed significantly from AUP females $(p=0.005)$ but not from males.

The curvature of the carapace showed a significant positive correlation with the total animal length $\left(r^{2}=0.340 ; p<0.001\right)$ in all crayfish analysed. The separate correlations between species and sexes resulted in all cases in lower, but still significant $(p<0.001)$ correlation coefficients lying between 0.172 and 0.289 .

The mean ratio of POL : CPW (postorbital length : carapace width) is $1.42 \pm 0.04$ (min. 1.28, max. 1.51) and $1.40 \pm 0.06$ (min. 1.28, max. 1.55) for noble crayfish and white clawed crayfish, respectively. The differences were significant neither between sexes nor between species.

The calculated angle of the carapace and the ratio of POL : CPW showed a correlation coefficient of $r^{2}=0.548$ for males and $r^{2}=0.616$ for females in AUP, and 
$r^{2}=0.715$ and $r^{2}=0.661$ for ASA males and females, respectively. All correlations were highly significant $(p<0.001)$.

Multivariate discriminant analysis represents a valuable tool to identify the characters best suited for the distinction of groups. Thus, it was also applied to differentiate the sexes in both species. Whereas for ASA all morphometric parameters (except ABD, CPW, HEL, $A R L$ and ratio POL : CPW) showed significant differences between sexes, for AUP only about half of the parameters, mostly those describing the claws and the abdomen differed significantly. In both species ABW was the most important parameter for differentiation of the sexes with the highest standardized canonical discriminant function coefficient, which was 0.964 for ASA and 0.999 for AUP. The other selected variables were CLL $(-0.412)$, TL $(-0.336)$, TEL $(0.317)$ and CGW $(-0.251)$ for $A$. astacus and CLL $(-0.517)$ and CEW $(-0.386)$ for $A$. pallipes.

The percentage of the correct classification was $100 \%$ for both sexes of AUP and for ASA males, and $97.3 \%$ for ASA females. In all cases cross validation gave the same results as the classification of the original cases.

\section{Differences within species and sexes}

Significant differences in carapace shape between populations (for AUP) and regions (for ASA) were only found for males (Figure 3 and 4). The ratio of POL/CPW in males of AUP differed significantly between KRB and ANG $(p=0.011)$, and between $K R B$ and ENT $(p=0.007)$. There was no significant difference in carapace curvature between males from different AUP populations. The males of ASA from South Tyrol (SÜD) differed significantly from RTS (carapace curvature: $p=0.049$; ratio POL : CPW: $p=0.041$ ) and from KUF (carapace curvature: $p=0.023$ ). Although the differences in those two parameters between the males of the other regions and all females were not significant, a tendency of splitting was visible (Figure 3A, 4A, 4B). ASA males for example showed a separation between the groups from north and south of the Alps only in the carapace curvature (Figure $3 \mathrm{~A}$ ).

A better distinction between the different crayfish groups was obtained with the multivariate discriminant analysis. Within the selected set of morphometric parameters the stepwise method gave different measurements for discriminating the groups. The rostrum was shown to be an important character, ROL and/or ROW, being present in all four sets of the selected variables from the stepwise analysis (Table II). For ASA males ROW (loading in discriminant function 1: - 1.007) was the most important factor but the loadings were also high for the other groups (Table II). With this analysis the populations of $A$. pallipes differed chiefly with regard to the normalized total length. The overall number of correctly classified cases was $60.9 \%$ for ASA males and $68.7 \%$ for ASA females and $80.9 \%$ for AUP males and $96.6 \%$ for AUP females (Table III). For detailed results of the discriminant analysis see Table II and Table III.

For $A$. astacus a plot of the first two discriminant functions of the different regions showed similar results for both sexes. The groups KUF and RTS were not distinguishable whereas the other groups were separated (Figure 5). This was verified by comparing the percentage of correctly classified cases with geographical separation, where groups with a greater geographical distance showed higher percentages of correct classification (Figure 1 and Table III). More than two thirds of the males from MIE and SÜD were sorted into their correct group whereas only $49.1 \%$ of male individuals from KUF were classified correctly and another $29.1 \%$ were wrongly classified as RTS. $80 \%$ and $90.9 \%$ of the females from $S U ̈ D$ and OST, respectively, were correctly associated and of the females from RTS $47.4 \%$ were classified as RTS, but $31.6 \%$ as KUF. 

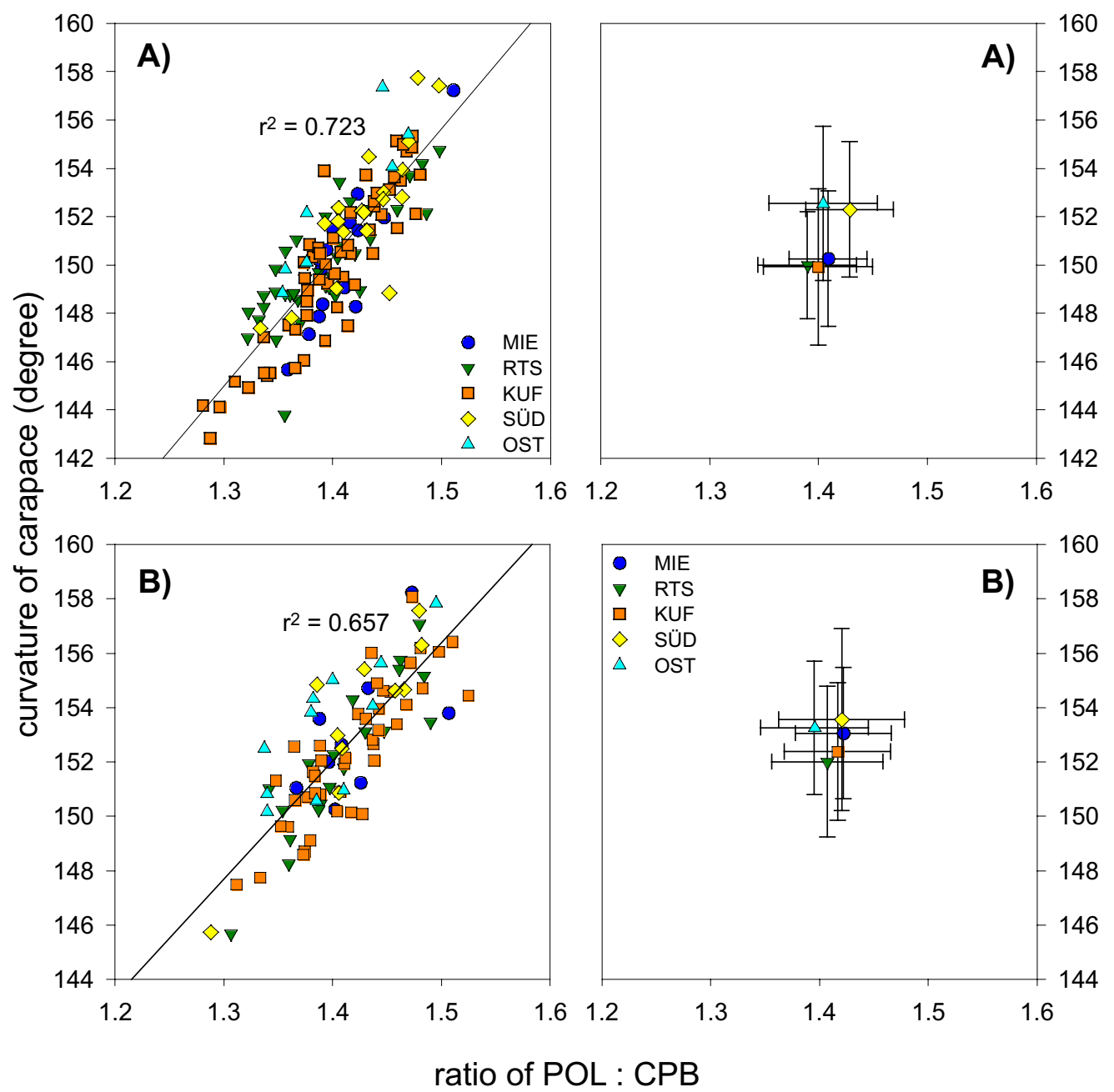

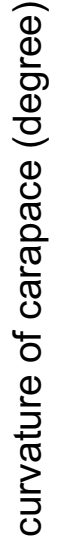

Figure 3

Correlation of the ratio POL/CPW with the lateral curvature of the carapace in A. astacus for the different geographic regions (see "material and methods" for abbreviations). Pictured are the single values with an over all regression (left) and means and standard deviations (right) of males (A) and females (B).

Figure 3

Corrélation des coefficient POL/CPW avec la courbure latérale pour $A$. astacus dans les différentes régions géographiques. (voir "material and methods" pour les abréviations). Les valeurs représentent à gauche les résultats obtenus sur chaque site avec une régression de toutes les données et à droite les moyennes et l'écart-type par région géographique, pour les mâles (A) et les femelles (B).

For $A$. pallipes the discriminant analysis provided strong evidence for the distinction of single populations, for both males and females (Figure $6 \mathrm{~A}$ and $\mathrm{B}$ ). Whereas between $H Y P$ and $K R B$ males (Figure $6 \mathrm{~A}$ ) virtually no overlap was found along the first discriminant function, the ANG males lay in between the HYP and KRB males and also overlapped to some degree with HYP. Therefore, by discriminant classification 5 HYP individuals 


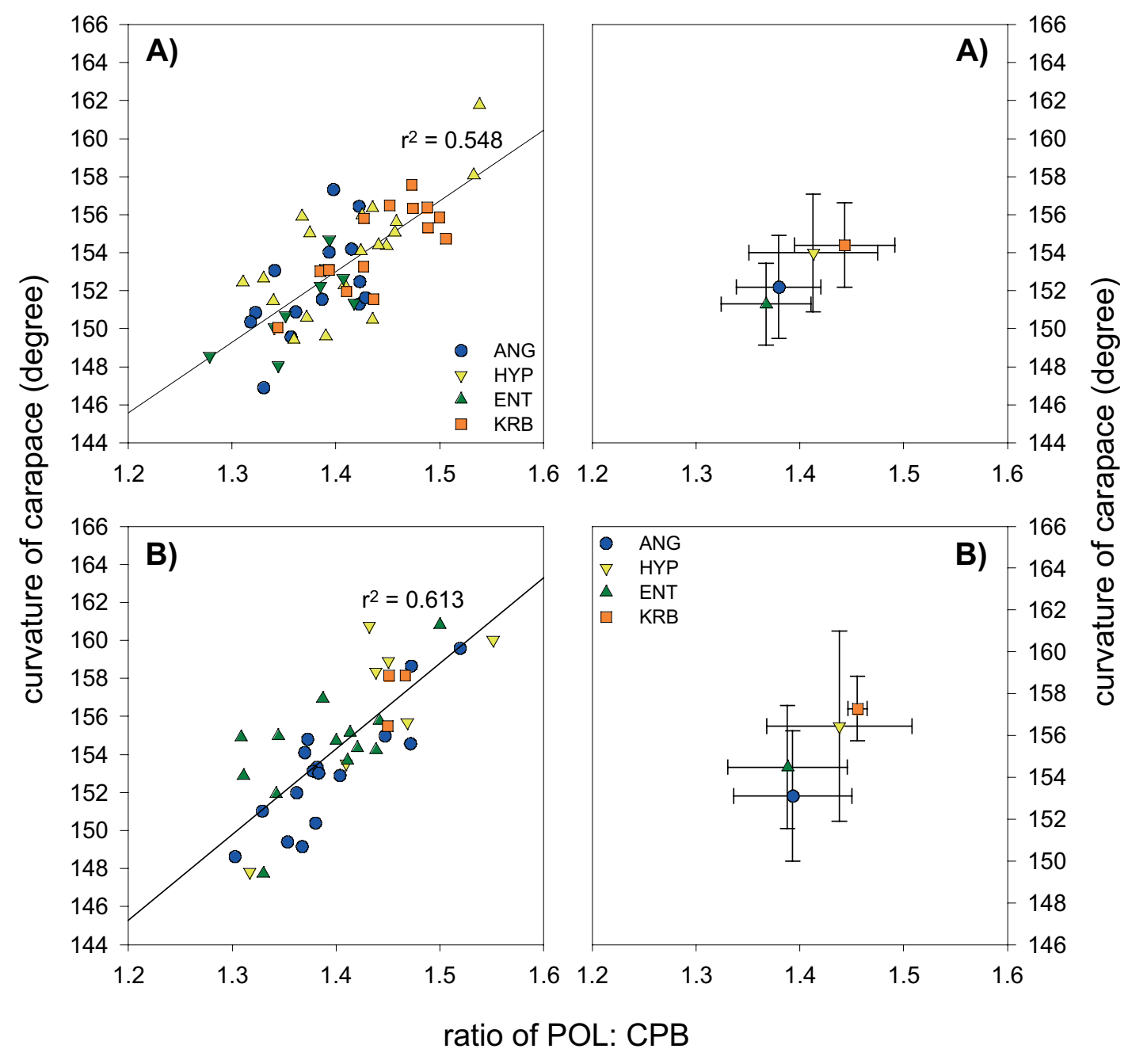

Figure 4

Correlation of the ratio POL/CPW with the lateral curvature of the carapace for the different populations of A. pallipes (see "material and methods" for abbreviations). Pictured are the single values with an over all regression (left) and means and standard deviations (right) of males (A) and females (B).

Figure 4

Corrélation des coefficients POL/CPW avec la courbure latérale pour les différentes populations d'A. pallipes. (voir "material and methods" pour les abréviations). Les valeurs représentent, pour les mâles $(A)$ et pour les femelles (B), à gauche, les résultats obtenus pour chaque population par régression de toutes les données, et à droite, les moyennes et la déviation standard par région géographique.

(26.3\%) of the males were assumed to fall into the ANG population and another two ANG individuals (14.3\%) were grouped into KRB. For the males of $K R B$ and the females of ENT the predicted group membership was correct for all individuals (Figure $6 \mathrm{~A}$ and $\mathrm{B}$, Table III). 
Table II

Discriminant Analysis: Standardized canonical discriminant function coefficients for the different crayfish groups for the morphological parameters (see Figure $2 \mathrm{~A}$ and B for location) and each discriminant function. Eigenvalue, percentage of explained variance, cumulative percentage of the variance and canonical correlation coefficient are given as well.

\section{Tableau II}

Analyse discriminante : Coefficients de la fonction canonique discriminante pour les différents groupes d'écrevisses pour les paramètres morphologiques (voir Figure 2A et B pour localisation) et pour chaque fonction discriminante utilisée. Eigenvalue, pourcentage de la variance expliquée, pourcentage cumulatif de la variance ainsi que coefficient de la corrélation canonique.

\begin{tabular}{|c|c|c|c|c|}
\hline Group & Morphol. parameter & Function 1 & Function 2 & Function 3 \\
\hline \multirow{8}{*}{ ASA males } & $\mathrm{ROL}$ & 0.352 & -0.341 & 0.743 \\
\hline & ROW & -1.007 & 0.196 & 0.387 \\
\hline & ARW & 0.175 & 0.580 & -0.264 \\
\hline & HEW & 0.634 & 0.543 & 0.313 \\
\hline & eigenvalue & 0.627 & 0.386 & 0.124 \\
\hline & explained variance\% & 55.1 & 33.9 & 10.9 \\
\hline & cumulative\% & 55.1 & 89.1 & 100.0 \\
\hline & canonical correlation & 0.621 & 0.528 & 0.333 \\
\hline \multirow[t]{10}{*}{ ASA females } & ROL & -0.493 & -0.082 & 0.789 \\
\hline & ROW & 0.453 & -0.171 & 0.431 \\
\hline & HEW & 0.402 & 0.684 & 0.274 \\
\hline & CGW & 0.345 & 0.491 & -0.370 \\
\hline & $A B L$ & -0.444 & 0.371 & 0.031 \\
\hline & TEL & 0.201 & -0.780 & -0.126 \\
\hline & eigenvalue & 1.087 & 0.659 & 0.279 \\
\hline & explained variance\% & 53.7 & 32.5 & 13.8 \\
\hline & cumulative $\%$ & 53.7 & 86.2 & 100.0 \\
\hline & canonical correlation & 0.722 & 0.630 & 0.467 \\
\hline \multirow[t]{8}{*}{ AUP males } & ROL & 0.448 & 0.880 & \\
\hline & CPW & 0.538 & 0.906 & \\
\hline & CEW & 0.742 & -0.722 & \\
\hline & $\mathrm{TL}$ & -1.488 & 0.031 & \\
\hline & eigenvalue & 2.492 & 0.413 & \\
\hline & explained variance\% & 85.8 & 14.2 & \\
\hline & cumulative $\%$ & 85.8 & 100.0 & \\
\hline & canonical correlation & 0.845 & 0.540 & \\
\hline \multirow[t]{7}{*}{ AUP females } & $\mathrm{CLH}$ & 0.705 & & \\
\hline & ROW & 1.257 & & \\
\hline & $\mathrm{TL}$ & -1.374 & & \\
\hline & eigenvalue & 3.099 & & \\
\hline & explained variance\% & 100 & & \\
\hline & cumulative\% & 100 & & \\
\hline & canonical correlation & 0.869 & & \\
\hline
\end{tabular}




\section{Table III}

Discriminant analysis: Percentage of correct classifications for original and cross-validated cases. Missing numbers indicate groups, which were not present in the analysis due to a small number of caught and measured adult individuals.

Tableau III

Analyse discriminante: Pourcentage des classifications correctes pour les cas originaux et cross validés. L'absence de valeurs signifie que le groupe n'a pas été pris en compte dans l'analyse en raison du nombre trop faible d'individus adultes capturés et mesurés.

\begin{tabular}{ccccc}
\hline \multirow{2}{*}{ Crayfish groups } & \multicolumn{2}{c}{ Original cases } & \multicolumn{2}{c}{ Cross-validated } \\
& males & females & males & females \\
\hline A. astacus & & & & \\
MIE & 66.7 & $/$ & 60.0 & $/$ \\
RTS & 71.8 & 47.4 & 71.8 & 47.4 \\
KUF & 49.1 & 69.8 & 45.5 & 60.5 \\
SÜD & 68.4 & 80.0 & 68.4 & 70.0 \\
OST & $/$ & 90.9 & $/$ & 90.9 \\
all A. astacus & 60.9 & 68.7 & 58.6 & 62.7 \\
A. pallipes & & & & \\
ENT & $/$ & 100.0 & $/$ & 92.3 \\
ANG & 78.6 & 93.8 & 71.4 & 93.8 \\
HYP & 68.4 & $/$ & 68.4 & $/$ \\
KRB & 100.0 & $/$ & 92.9 & $/$ \\
all A. pallipes & 80.9 & 96.9 & 76.6 & 93.1 \\
\hline
\end{tabular}

As an estimation of the model accuracy, the cross-validation showed similar percentages of correctly classified cases as those of the original cases. In nearly half of them no difference was detected (Table III).

\section{DISCUSSION}

Morphometry in crayfish is well investigated (SAILA and FLOWERS, 1969; CHAMBERS, PAYNE and KENNEDY, 1979; SCHULZ and KIRCHLEHNER, 1984; HUNER, LINDQVIST and KONONEN, 1995; LUTZ and WOLTERS, 1995; GRANDJEAN et al., 1997; GRANDJEAN and SOUTY-GROSSET, 2000; STREISSL and HÖDL, 2002), but most of these studies dealt mainly with sexual dimorphism and changes of body proportions at the onset of maturity. Our results on morphological characterisation of noble and white-clawed crayfish derived from different populations indicate that there were differences not only at the already known level of sexes (see also e.g. GRANDJEAN et al., 1997; GRANDJEAN and SOUTY-GROSSET, 2000; STREISSL and HÖDL, 2002) but also between populations or geographic regions within the sex. Comparison of simple key data of the crayfish carapace (lateral curvature and ratio POL/CPW) showed that there were differences in the morphology as well as in the body proportions of crayfish originating from distinct populations.

In marine and freshwater fish the use of morphometric measurements is common for stock identification and often used as for example in chinook salmon Oncorhynchus tshawytscha (Walbaum in Artedi, 1792) (WINANS, 1984), horse mackerel Trachurus trachurus (L.) (MURTA, 2000), australian bass Macquaria novemaculeata (Steindachner, 


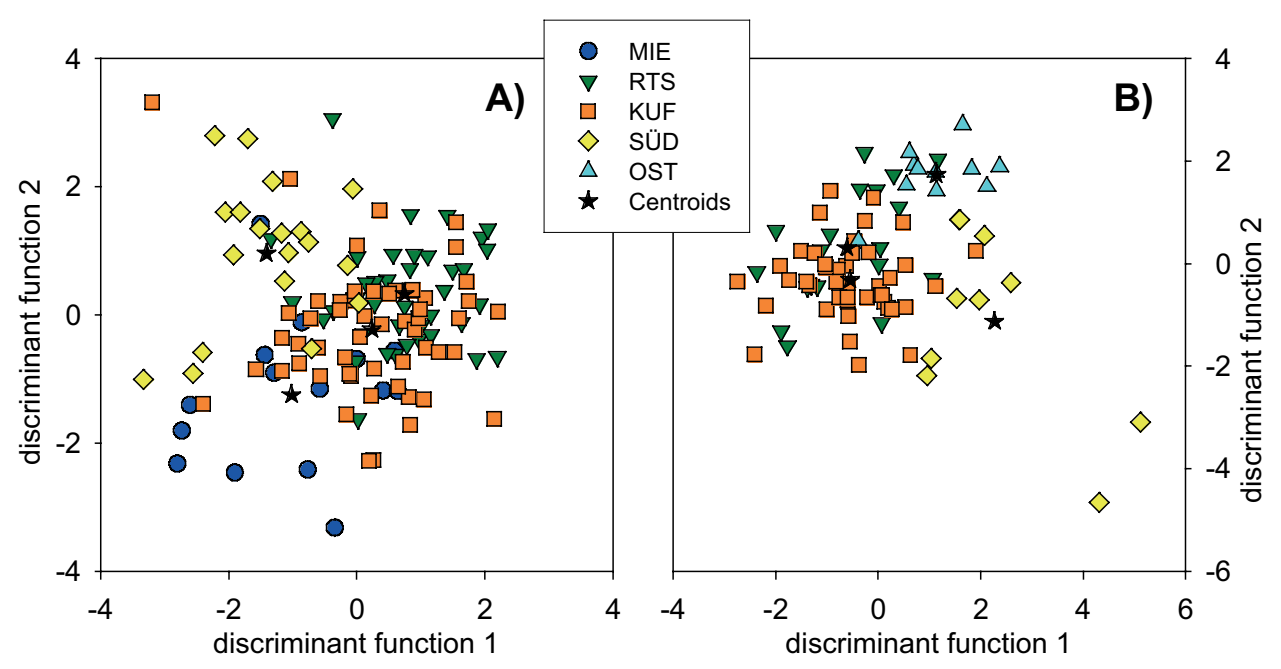

Figure 5

Discrimination of geographic regions by the first two discriminant functions for males (A) and females (B) of Astacus astacus. See "material and methods" for abbreviations and Table II for details on the discriminant functions.

Figure 5

Discrimination des régions géographiques à l'aide des deux premières fonctions discriminantes pour les mâles (A) et pour les femelles (B) pour Astacus astacus. Voir "material and methods" pour les abréviations et le tableau II pour les détails des fonctions discriminantes.
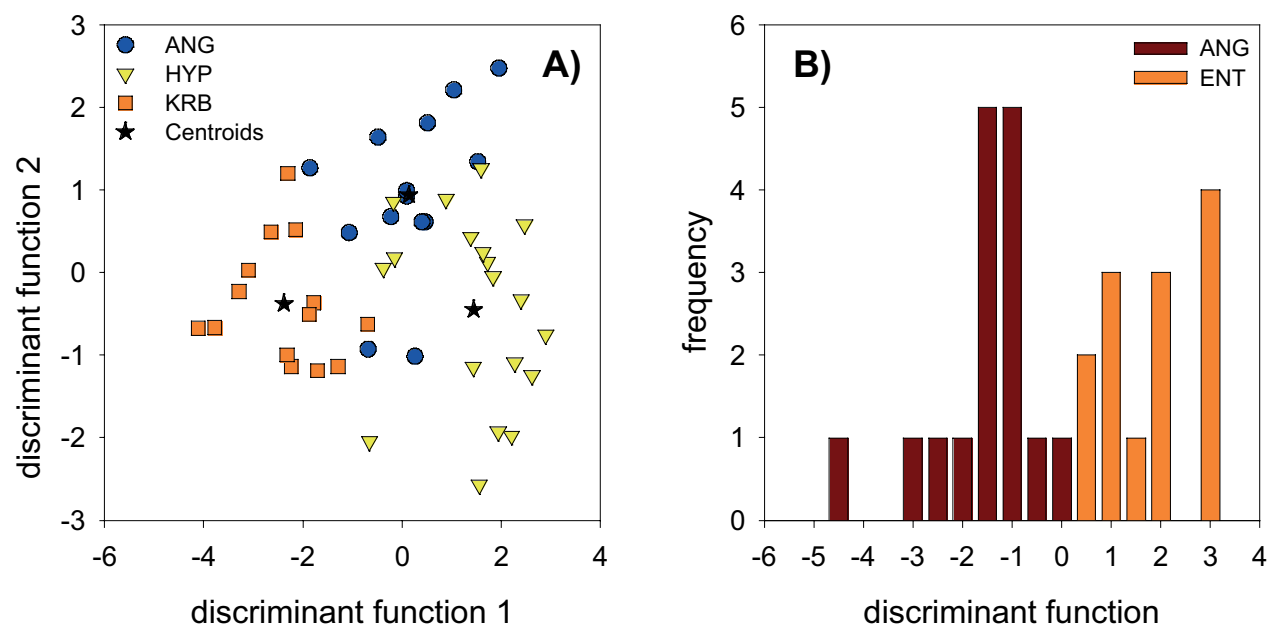

Figure 6

Discrimination of the different populations of Austropotamobius pallipes by the first two discriminant functions for males (A) and one discriminant function for females (B). See "material and methods" for abbreviations and Table II for details on the discriminant functions.

Figure 6

Discrimination des différents populations d'Austropotamobius pallipes par les deux première fonctions discriminantes pour les mâles $(A)$ et une fonction discriminante pour les femelles (B). Voir "material and methods" pour les abréviations et le tableau II pour les détails des fonctions discriminantes. 
1866) (JERRY and CAIRNS, 1998), brown trout Salmo trutta (L.) (PAKKASMAA, 2001), three species of Sparidae (PALMA and ANDRADE, 2002), red mullet Mullus barbatus (L.) (MAMURIS et al., 1998), chub Leuciscus cephalus (L.) (HÄNFLING and BRANDL, 1998), rock bass Ambloplites rupestris (Rafinesque, 1817) and pumpkinseed Lepomis gibbosus (L.) (BRINSMEAD and FOX, 2002) and brook charr Salvelinus fontinalis (Mitchill, 1814) (DYNES et al., 1999). Our results on crayfish species demonstrated successful classification when discriminant analysis was used. In most of the cases original classification and crossvalidation yielded a similar percentage of correctly predicted group membership.

We also detected a relationship between the geographic distance and the percentage of correct classifications. Discriminant analysis allowed a good discrimination between all populations of $A$. pallipes (Figure 6) and most of $A$. astacus groups (Figure 5). For A. pallipes, this is supported by genetic mitochondrial and microsatellite analyses, where all four populations are to be considered as isolated without gene-flow between them (BARIC et al., 2005a,b). The lack of discrimination in A. astacus as well as the great differences obtained regarding the percentage of correct classification for the other groups (Table III) were probably due to the vicinity of the locations. In addition, stocking activities and/or mixing of individuals of different stocks during the last decades cannot be excluded for some of the populations in the regions KUF and RTS. In general the stocking of the Reintalerseen (RTS) was conducted after 1930, but the source population is not known definitely (Y. MACHINO, pers. comm.).

Another parallelism in fish and crayfish becomes apparent when males and females are considered. JERRY and CAIRNS (1998) applied the discriminant analysis on a number of Australian bass populations, and concordant to our study males differed in more characters than females.

The results presented here point out the importance of including carapace shape in morphometric analyses (identified by differences in the shape specific measurements as well as high loadings in the discriminant analysis) as also described by SAILA and FLOWERS (1969) and CHAMBERS, PAYNE and KENNEDY (1979) for other decapods. An advantage of carapace measurements is that they are neither influenced by loss and regeneration (like claws) nor by abdominal muscle contractions. In addition, the angle of the carapace curvature turned out to be species specific, at least for $A$. astacus and A. pallipes, where our results provided significant differences. Some of them may result from unequal sizes, however, this seemed not to be very important as the correlation between total length and curvature of the carapace was very low.

Although our results are considered preliminary, they demonstrate the morphological distinctiveness of single crayfish populations and regions. Only a few characters were needed for a good classification. Such groupings based on morphology may represent adaptations to the environment on a rather short time scale compared to genetics, as BEGG, FRIEDLAND and PEARCE (1999) assumed in their work. An example in crayfish is the areolar width, which is apparently correlated with water velocity. Already HOBBS (1942) observed, that the branchial chambers were bigger, and therefore the areolar widths smaller, in crayfish inhabiting lentic waters compared to those from running waters.

Phenotypic plasticity, due to adaptations to the local environmental conditions, may play a role in the expression of morphological differences between several populations - but on the other hand, populations living under similar ecological conditions would be subjected to similar phenotypic plasticity and may show similar morphological characteristics. Thus, morphometry can be a suitable tool for stock identification, if the species under investigation show a low potential for phenotypic plasticity or are subjected to different ecological conditions. For many field studies, morphometry is a fast and easily applicable method with low impact for the single specimen and is considered important complementary to genotypic characterisation in species protection programs. 


\section{ACKNOWLEDGEMENTS}

We wish to thank Bettina Sonntag, Sebastian Voigt, Michaela Salcher and Christian Berger for field work assistance, Hanno Ulmer for the help with statistical analysis and Claude Hansen for the French translation. Funding was provided by the Interegg III program of the EU (Project "Crayfish-Geneflow"), the Tiroler Landesregierung and the Autonomous Province of Bozen/Bolzano.

\section{REFERENCES}

BARIC S., HÖLLRIGL A., FÜREDER L., DALLA VIA J., 2005a. Mitochondrial and microsatellite DNA analyses of Austropotamobius pallipes in South Tyrol (Italy) and Tyrol (Austria). In: FÜREDER L. and SOUTY-GROSSET C., 2005: European native crayfish in relation to land-use and habitat deterioration with a special focus on Austropotamobius torrentium, CRAYNET, Volume 3, Bull. Fr. Pêche Piscic., 376377, 599-612.

BARIC S., HÖLLRIGL A., KERSCHBAMER C., FÜREDER L., PETUTSCHNIG J., DALLA VIA J., 2005b. Update of the molecular phylogeny of the Austropotamobius pallipes species complex by including specimens from South Tyrol (Italy) and Carinthia (Austria). In: FÜREDER L. and SOUTY-GROSSET C., 2005: European native crayfish in relation to land-use and habitat deterioration with a special focus on Austropotamobius torrentium, CRAYNET, Volume 3, Bull. Fr. Pêche Piscic., 376377, 627-636.

BEGG G.A., FRIEDLAND K.D., PEARCE J.P., 1999. Stock identification and its role in stock assessment and fisheries management: an overview. Fisheries Research, 43, 1-8.

BRINSMEAD J., FOX M.G., 2002. Morphological variation between lake- and streamdwelling rock bass and pumpkinseed populations. Journal of Fish Biology, 61, 1619-1638.

BÜHL A., ZÖFEL P., 2002. SPSS 11. Einführung in die moderne Datenanalyse unter Windows. 8. überarbeitete u. erweiterte Auflage. Pearson Education Deutschland $\mathrm{GmbH}$, München, $757 \mathrm{p}$.

CHAMBERS C.L., PAYNE J.F., KENNEDY M.L., 1979. Geographic variation in the dwarf crayfish, Cambarellus puer Hobbs (Decapoda, Cambaridae). Crustaceana, 36 (1), 39-55.

CUKERZIS J.M., 1988. Astacus astacus in Europe. In: HOLDICH, D.M., LOWERY R.S (eds), Freshwater Crayfish: Biology, Management and Exploitation. Chapman \& Hall, London, 309-340.

DYNES J., MAGNAN P., BERNATCHEZ L., RODRÍGUEZ M.A., 1999. Genetic and morphological variation between two forms of lacustrine brook charr. Journal of Fish Biology, 54, 944-972.

FÜREDER L., HANEL R., 2000. Flusskrebse in den Gewässern Nord- und Osttirols: Verbreitung, ökologische Bedeutung und Schutzmaßnahmen. Berichte des naturwissenschaftlich-medizinischen Vereins in Innsbruck, 87, 221-241.

FÜREDER L., OBERKOFLER B., MACHINO Y., 2002. Flusskrebse in den Gewässern Südtirols: Verbreitung, ökologische Bedeutung und Gefährdung. Berichte des naturwissenschaftlich-medizinischen Vereins in Innsbruck, 89, 179-199.

FÜREDER L., OBERKOFLER B., HANEL R., LEITER J., THALER B., 2003. The freshwater crayfish Austropotamobius pallipes in South Tyrol: Heritage Species and Bioindicator. In: REYNOLDS J. and SOUTY-GROSSET, 2003: The endangered 
native crayfish Austropotamobius pallipes, Bioindicator and heritage species, CRAYNET, Volume 1, Bull. Fr. Pêche Piscic., 370-371, 79-95.

FÜREDER L., REYNOLDS J.D., 2003. Is Austropotamobius pallipes a good bioindicator? In: REYNOLDS J. and SOUTY-GROSSET, 2003: The endangered native crayfish Austropotamobius pallipes, Bioindicator and heritage species, CRAYNET, Volume 1, Bull. Fr. Pêche Piscic., 370-371, 157-163.

GHERARDI F., HOLDICHD M., 1999. Crayfish in Europe as alien species. How to make the best of a bad situation. Crustacean Issues 11, A.A. Balkema, Rotterdam, Brookfield, p. 1-299.

GRANDJEAN F., ROMAIN D., AVILA-ZARZA C., BRAMARD M., SOUTY-GROSSET C., MOCQUARD J.P., 1997. Morphometry, sexual dimorphism and size at maturity of the white-clawed crayfish Austropotamobius pallipes pallipes (Lereboullet) from a wild French population at Deux-Sèvres (Decapoda, Astacidea). Crustaceana, 70 (1), 31-44.

GRANDJEAN F., SOUTY-GROSSET C., 2000. Genetic and morphological variation in the endangered crayfish species, Austropotamobius pallipes (Lereboullet) (Crustacea, Astacidae) from the Poitou-Charentes region (France). Aquatic Sciences, 62, 1-19.

HÄNFLING B., BRANDL R., 1998. Genetic and morphological variation in a common European cyprinid, Leuciscus cephalus within and across Central European drainages. Journal of Fish Biology, 52, 706-715.

HAGER J., 1996. Edelkrebse. Biologie - Zucht - Bewirtschaftung. Leopold Stocker Verlag, Graz, 128 p.

HAIR J.F. JR., ANDERSON R.E., TATHAM R.L., BLACK W.C., 1998. Multivariate Data Analysis. $5^{\text {th }}$ Edition. Prentice-Hall Inc., New Jersey. XX $+730+12 p$.

HOBBS H.H. JR., 1942. The crayfishes of Florida. Univ. Florida Pub., Biol. Sci. Ser., 2: 1-176, in CHAMBERS C.L., PAYNE J.F., KENNEDY M.L., 1979. Geographic variation in the dwarf crayfish, Cambarellus puer Hobbs (Decapoda, Cambaridae). Crustaceana, 36 (1), 39-55.

HUNER J.V., LINDQVIST O.V., KONUNEN H., 1995. Sexual dimorphism and yield of edible products from a stunted, by commercial standards, population of noble crayfish (Astacus astacus Linne) in central Finland. Freshwater Crayfish, 8, 668-679.

HUOLILA M., MARJOMÄKI T.J., LAUKKANEN E., 1997. The success of crayfish stocking in a dredged river with and without artificial shelter increase. Fisheries Research, 32, 185-189.

IMRE I., MCLOUGHLIN R.L., NOAKES D.G.L., 2002. Phenotypic plasticity in brook charr: changes in caudal fin induced by water flow. Journal of Fish Biology, 61, 11711181.

JAMES C.J., MCCULLOCH C.E., 1990. Multivariate analysis in ecology and systematics: panacea or Pandora's Box? Annual Review of Ecology and Systematics, 21, 129166.

JERRY D.R., CAIRNS S.C., 1998. Morphological variation in the catadromous Australian bass, from seven geographically distinct riverine drainages. Journal of Fish Biology, $52,829-843$.

LUTZ C.G., WOLTERS R.W., 1995. Multivariate morphological variation in a population of red swamp crayfish Procambarus clarkii (Girard). Freshwater Crayfish, 8, 56-67.

MAMURISZ., APOSTOLIDIS A.P., PANAGIOTAKIP., THEODOROUA.J., TRIANTAPHYLLIDIS C., 1998. Morphological variation between red mullet populations in Greece. Journal of Fish Biology, 52, 107-117. 
MURTA G.A., 2000. Morphological variation of horse mackerel (Trachurus trachurus) in the Iberian and North African Atlantic: implications for stock identification. Journal of Marine Science, 57, 1240-1248.

PAKKASMAA S., 2001. Morphological differentiation among local trout (Salmo trutta) populations. Biological Journal of the Linnean Society, 72, 231-239.

PALMA J., ANDRADE J.P., 2002. Morphological study of Diplodus sargo, Diplodus puntazzo and Lithognathus mormyrus (Sparidae) in the Eastern Atlantic and Mediterranean Sea. Fisheries Research, 57, 1-8.

SAILA S.B., FLOWERS J.M., 1969. Geographic morphometric variation in the American lobster. Systematic Zoology, 18, 330-338.

SCHULZ N., KIRCHLEHNER W., 1984. Der Steinkrebsbestand Astacus torrentium (Schrank) im Spintikbach (Kärnten Österreich). Österreichs Fischerei, 37, 47-57.

SINT D., FÜREDER L., 2004. Reintroduction of Astacus astacus L. in East Tyrol. In: TAUGBØL T. and SOUTY-GROSSET C., 2004: European native crayfish with a special focus on Astacus astacus: linking socioeconomics and conservation, CRAYNET, volume 2, Bull. Fr. Pêche Piscic., 372-373, 301-314.

SKURDAL J., TAUGBØL T., 2001. Crayfish of commercial importance. Astacus. In: HOLDICH D.M., (Ed.), Biology of freshwater crayfish. Blackwell Science, Oxford, p. 467-510.

STREISSL F., HÖDL W., 2002. Growth, morphometrics, size at maturity, sexual dimorphism and condition index of Austropotamobius torrentium Schrank. Hydrobiologia, 477, 201-208.

SWAIN D.P, FOOTE C.J., 1999. Stock and chameleons: the use of phenotypic variation in stock identification. Fisheries Research, 43, 113-128.

WESTIN L., GYDEMO R., 1995. The proportion of mature females of the noble crayfish, Astacus astacus, in ponds and under indoor conditions and the effect of trappability. Freshwater Crayfish, 8, 157-169.

WINANS G.A., 1984. Multivariate Morphometric Variability in Pacific Salmon: Technical Demonstration. Canadian Journal of Fisheries and Aquatic Sciences, 41, 11501159. 